\title{
Adapting and Surviving: Intra and Extra-Cellular Remodeling in Drug-Resistant Gastric Cancer Cells
}

\author{
Sabino Russi ${ }^{1,+} \mathbb{1}^{+}$, Henu Kumar Verma ${ }^{2,3,+}$, Simona Laurino ${ }^{1}\left(\mathbb{0}\right.$, Pellegrino Mazzone ${ }^{3}$, \\ Giovanni Storto ${ }^{4}$, Anna Nardelli ${ }^{5}$, Pietro Zoppoli ${ }^{1}$ (D) , Giovanni Calice ${ }^{1} \mathbb{1}$, \\ Francesco La Rocca ${ }^{6}\left(\mathbb{D}\right.$, Alessandro Sgambato ${ }^{7}$, Valeria Lucci ${ }^{8}$, Geppino Falco ${ }^{3,8, *, \ddagger}$ and \\ Vitalba Ruggieri ${ }^{1, *, \ddagger}$ \\ 1 Laboratory of Preclinical and Translational Research, IRCCS-Referral Cancer Center of Basilicata (CROB), \\ 85028 Rionero in Vulture (PZ), Italy \\ 2 Institute of Experimental Endocrinology and Oncology, National Research Council, 80131 Naples, Italy \\ 3 Section of Stem Cell and Development, Istituto di Ricerche Genetiche "Gaetano Salvatore" Biogem s.c. a.r.l., \\ 83031 Ariano Irpino, Italy \\ 4 Department of Nuclear Medicine, IRCCS—Referral Cancer Center of Basilicata (CROB), 85028 Rionero in \\ Vulture (PZ), Italy \\ 5 Istituto di Biostrutture e Bioimmagini, Consiglio Nazionale delle Ricerche, 80145 Napoli, Italy \\ 6 Laboratory of Clinical Research and Advanced Diagnostics, IRCCS-Referral Cancer Center of \\ Basilicata (CROB), 85028 Rionero in Vulture (PZ), Italy \\ 7 Scientific Direction, IRCCS-Referral Cancer Center of Basilicata (CROB), 85028 Rionero in Vulture (PZ), Italy \\ 8 Department of Biology, University of Naples Federico II, 80126 Naples, Italy \\ * Correspondence: geppino.falco@unina.it (G.F.); vitalba.ruggieri@crob.it (V.R.); \\ Tel.: +39-081-679092 (G.F.); +39-0972-726239 (V.R.) \\ + These authors contributed equally to this work. \\ $\ddagger$ Contributed equally as last authors.
}

Received: 3 July 2019; Accepted: 29 July 2019; Published: 31 July 2019

\begin{abstract}
Despite the significant recent advances in clinical practice, gastric cancer (GC) represents a leading cause of cancer-related deaths in the world. In fact, occurrence of chemo-resistance still remains a daunting hindrance to effectiveness of the current approach to GC therapy. There is accumulating evidence that a plethora of cellular and molecular factors is implicated in drug-induced phenotypical switching of GC cells. Among them, epithelial-mesenchymal transition (EMT), autophagy, drug detoxification, DNA damage response and drug target alterations, have been reported as major determinants. Intriguingly, resistant GC phenotype may be the result of GC cell-induced tumor microenvironment (TME) remodeling, which is currently emerging as a key player in promoting drug resistance and overcoming cytotoxic effects of drugs. In this review, we discuss the possible mechanisms of drug resistance and their involvement in determining current GC therapies failure.
\end{abstract}

Keywords: gastric cancer; drug resistance; cellular reprogramming; cell behavior

\section{Introduction}

In the last decade, remarkable progress has been made in understanding the complex molecular mechanisms responsible for the onset and progression of human gastric cancer (GC). It represents the second most common cause of cancer deaths worldwide [1]. The incidence of GC varies significantly among different geographical areas, with higher rates in Eastern Asia, European and South America Countries and lower ones in North America and Africa regions [2,3]. 
To date, the most common therapeutic options for GC remain surgery and/or chemotherapy [4], although only surgical resection is considered curative, ensuring a five-year overall survival rate of $60-80 \%$ [5], in the case of an early stage diagnosis [6].

Several chemotherapeutic strategies have been used in patients with unresectable tumors to relieve symptoms and decrease the risk of recurrence [7] and metastasis [8,9], with a 5-year overall survival of $20-35 \%$ [10,11]. Moreover, compared with surgery alone, perioperative chemotherapy is able to significantly improve prognosis of patients with resectable GC [12,13]. However, at present, in $70-90 \%$ of cases, chemotherapy is unable to inhibit tumor cell growth [14], cancer cell invasiveness and metastasis spread, leading to drug resistance [15-18].

Chemo-resistance of tumor cells occurs through two universally accepted mechanisms [19]: It may be already pre-existent at diagnosis, meaning that tumor cells are intrinsically resistant to the chemotherapeutic agent [20], or it can be induced after the exposure of cancer cells to the drug [21-23]. These two resistance profiles are defined as intrinsic and acquired resistance, respectively, and they are both related to tumor cells, as well as to tumor microenvironment (TME) characteristics [24,25]. Hence, elucidation of the molecular mechanisms underlying drug resistance is of paramount importance in order to improve GC patients' survival. Nevertheless, the molecular mechanisms of drug resistance in GC, such as involvement of host factors [26], substantial changes in genetic and epigenetic factors [27,28], and mutations in drug targets, have been only partially defined [29].

Here, we reviewed the recent literature on the molecular mechanisms by which GC cells promote intra and extra-cellular remodeling for overcoming anticancer drugs effects.

\section{Role of Microenvironment in Tumor Growth and Chemo-Resistance}

The role of TME in tumor progression and drug resistance is an attractive area of investigation [30-32], mainly focusing on the molecular mechanisms underlying the TME responsiveness to anticancer drugs and the crosstalk between cancer cells and their environment [33]. The interaction between tumor cells and stromal components involves growth factors, chemokines, cytokines and non-cellular components such as the extracellular matrix (ECM), all contributing to tumor development and drug resistance in different types of cancers, including GC [34-37]. Furthermore, there is emerging evidence suggesting that the accumulation of various stromal cells (SC) such as fibroblasts, endothelial cells, adipose tissue-derived stromal cells (ATDSC), several immune cells or inflammatory cells and bone marrow-derived stem cells (BMDSC) could be involved in drug resistance through cell-to-cell communication, tumor-to-stromal cell communication [38], and tumor-to-ECM interaction [39].

\subsection{Angiogenesis and Hypoxia}

Angiogenesis is a prerequisite for a rapid expansion of the tumor cell population, favoring an increase in tumor size and intravasation [40]. It has also been hypothesized that tumor angiogenesis is primarily involved in tumor cell apoptosis inhibition and chemo-resistance. Furthermore, tumor angiogenesis is correlated with the prognosis of several tumors, including GC [41]. A primary driving force of angiogenesis is the reduction of oxygen levels, so-called hypoxia, caused by the abnormal proliferation of cancer cells and the anomalous organization of the neo-formed vasculature network [42,43]. Hypoxia leads to the expression of several genetic factors involved in tumor progression and metastasis in GC $[44,45]$. The most important one is hypoxia-inducible factor- $1 \alpha$ (HIF-1 $\alpha$ ), which regulates cellular response to hypoxia [46]. HIF-1 $\alpha$ expression has been found to be significantly associated with drug resistance in GC [47,48]. Even if HIF- $1 \alpha$-dependent molecular mechanisms in chemo-sensitivity have been only partially elucidated, suppression of p53 and activation of nuclear factor $\mathrm{\kappa B}(\mathrm{NF}-\mathrm{kB}$ ) seem to play a key role in hypoxia-related 5-fluorouracil (5-FU) and cisplatin (CDDP) sensitivity in human GC cells [49]. It has been reported that HIF-1 $\alpha$ induces drug resistance to adjuvant chemotherapy with 5-FU in advanced GC patients [50]. Moreover, the overexpression of 
HIF- $1 \alpha$ leads to hypoxia-induced drug resistance by increasing the expression of Bcl-2, P-glycoprotein (P-gp) and MRP1, and reducing the expression of Bax [51].

\subsection{Angiogenesis and Growth Factors}

As suggested by many reports, angiogenesis in GC is controlled by various factors released by tumor and stromal cells. Furthermore, angiogenesis is responsible for tumor chemo-resistance [52]. Vascular endothelial growth factor family members (VEGFs) and their receptors represent important tumor angiogenesis inducers in GC [53]. The VEGFs are both mitogen and survival factors. It has been reported that patients with VEGF overexpressing tumors, compared to patients with VEGF negative tumors, develop resistance to chemotherapy and show a significantly poorer prognosis and shorter survival $[54,55]$. A previous study also reported that VEGF family expression is significantly associated with distant metastasis [56]. Consistently, upregulated VEGF-C expression is positively correlated with chemo-resistance in human GC cell lines whereas loss of VEGF-C inhibits metastasis by inducing apoptosis in vitro and in vivo [57].

Since the characterization of the VEGF family, several other factors have been described as regulators of angiogenesis in cancer. Among these, cancer-associated fibroblasts (CAFs) represent an abundant component in TME. During tumor progression, CAFs transdifferentiate from resident fibroblasts, endothelial cells, preadipocytes and bone marrow-derived mesenchymal stem cells (MSCs) and are able to deeply impact cancer behavior and anti-cancer treatment efficacy [58]. Innate and adaptive properties of CAFs indeed contribute to tumor progression and metastasis, as well as to chemo-resistance occurrence in different human cancers $[58,59]$. Several therapeutics approaches targeting CAF have been investigated to date, resulting in decreased tumor growth and also in cancer cells enhanced immunotherapy sensitivity [60]. Until now, the phenotype characterization and mechanism of interaction between GC cells and CAFs has not yet been fully elucidated. However, it has recently been reported that CAFs produce soluble tumor-promoting factors such as SDF-1/CXCL12 and promote GC cell invasiveness by inducing integrin beta1 clustering [60]. Increase of VEGF-A expressing CAFs, derived from bone marrow, was reported in mouse GC after co-activation of prostaglandin $\mathrm{E}_{2}$ $\left(\mathrm{PGE}_{2}\right)$ and Wnt signaling pathway [61]. GC cells and CAFs are also able to secrete IL-1, prostaglandin and sphingosin 1 phosphate (S1P), promoting chemo-resistance via IL-11/IL-11R/JAK/STAT3, an anti-apoptosis signaling pathway [62]. A recent study demonstrated that activated gastric CAFs correlate with poor prognosis and contribute to the increased resistance to 5-FU via paracrine action [63].

Several interleukins (ILs) have also been implicated in key angiogenic events modulation in GC. Overexpression of IL-8 in MKN45 gastric cancer cell line is responsible for increased cell-cell adhesion, cellular migration, invasion and resistance to oxaliplatin [64]. IL-33, a member of the IL-1 family, showed a close relationship with invasiveness, while IL-33 overexpression increased the activation of the JNK signaling pathway, protecting GC cells from platinum-induced apoptosis [65]. IL-6, one of the major cytokines, can induce the activation of STAT3 in GC tissue [66], and it has been found to be associated with trastuzumab resistance [67]. Tumor necrosis factor-related apoptosis-inducing ligand (TRAIL) is a TNF family member that promotes NF- $\mathrm{kB}$-signaling pathway mediated 5-FU resistance in GC cells [68,69]. A proliferation-inducing ligand (APRIL) is a TNF family member and a cytokine involved in CDDP resistance in GC cells [70]. To date, several targets playing a key role in the angiogenesis-mediated chemo-resistance have been discovered. Based on this evidence, several antiangiogenic factors are currently used in the treatment of GC to overcome chemo-resistance mechanisms [71,72].

\section{Role of Microenvironment in Tumor Growth and Chemo-resistance}

Epithelial-mesenchymal transition (EMT) is recognized as a crucial process in embryonic development of multicellular organisms and wound healing. The EMT was identified as a pivotal driver in tumors initiation and progression. This often-reversible trans-differentiation process, indeed, endows originally epithelial cells with migratory mesenchymal features and also with cancer stem cell 
(CSC) properties, such as tumorigenicity, self-renewal, apoptosis escaping, through a multistep and finely orchestrated reprogramming [73].

Far from being a univocal process, EMT consists, instead, of a wide spectrum of transitional states in which the interplay among several molecular mechanisms, from signal transduction pathways to epigenetic changes, microRNA and growth and transcription factors, exerts a key regulatory function [74-77].

The cross-talk between extra and intra-cellular signals involved in EMT process converges at profound cellular modifications, such as down-regulation of E-cadherin, a typical epithelial marker, and up-regulation of $\mathrm{N}$-cadherin and other mesenchymal proteins [76].

A large body of evidence highlights a close relationship between EMT status and cancer cell metastatic properties, chemo-resistance and worse clinical outcomes across a wide range of tumors, including GC [76,78-84].

One of the most recent findings demonstrated that the overexpression of miR-30 induces the occurrence of an epithelial-like phenotype associated with a higher CDDP sensitivity in mesenchymal resistant GC cells and that miR-30 is significantly down-regulated in chemo-resistant GC patients [85]. Moreover, the oncogenic protein TAZ (transcriptional co-activator with PDZ-binding motif) is highly expressed in CDDP-resistant GC cells and in GC patients. It is closely correlated with lymphatic metastasis and tumor TNM stages, and its depletion partially reverses EMT to mesenchymal-epithelial transition (MET) and sensitizes resistant cells to CDDP [86]. Furthermore, acquired resistance to lapatinib of HER2-positive GC cells has been revealed to be associated with Testican-1-mediated EMT [87], and CDDP resistance positively correlates with EMT induced by HER2 up-regulation [88]. Another recent study confirms the EMT role in CDDP chemo-resistance, demonstrating that knockdown of the translation initiation factor eIF5A2 promotes GC cells' sensitivity to the drug by reversing the EMT process and inhibiting CDDP action on EMT-related markers [89]. The EMT process has also been associated with acquired resistance to selective FGFR inhibitors in GC cells [90] and transient doxorubicin (DOX) treatment induced a $\beta$-catenin-dependent EMT, promoting GC cells migration ability as well [91].

Many reports support the notion that EMT is strictly related to the occurrence of CSCs-like properties in GC and many other tumor types [92]. The combination of stemness and EMT is an independent prognostic factor for GC patients' outcomes [93]. Recently, it has been reported that ectopic expression of embryonic stem cells transcription factor, NANOGP8, in GC cells, promotes sphere-forming and chemo-resistance by up-regulating EMT inducers and CSCs markers [94]. Moreover, expression of LGR5 and EMT-related genes in GC sphere cells is significantly associated with drug resistance [95]. Interestingly, targeting of gastric CSCs by the proton pump inhibitor, pantoprazole, inhibits 5-FU chemo-resistance via the EMT/ $\beta$-catenin pathways [96]. With respect to the molecular mechanisms connecting EMT to the occurrence of chemo-refractory cells with CSC phenotypes, compelling evidence exists supporting a major role for TGF- $\beta$ signaling and Wnt pathways [97]. It is also worth mentioning that EMT-related signaling functionally interacts with the autophagy pathway, which, as described below in more detail, is deeply intertwined with the fate of cancer cells. However, the relationship between EMT and autophagy seems to play a crucial role in cancer cells [98]. Intriguingly, autophagy exerts a dual effect on EMT, as well, by triggering or suppressing it, depending on the contextual conditions. The EMT process, in turn, has a dramatic impact on autophagy modulation, by regulating signal pathways, such as integrin, NF- $\mathrm{kB}$, Wnt and TGF- $\beta$ [99]. Considering the complexity of this interplay, unveiling mechanisms of their mutual regulation is challenging, but has potential clinical benefits in cancer therapy.

\section{Role of Autophagy in GC Chemo-Resistance}

Autophagy is a catabolic process that, in response to stress and starvation conditions, leads to engulfment, digestion and recycling of intra-cellular components in order to sustain cellular survival. Autophagy plays a key homeostatic and protective function both in physiological and pathological 
contexts [100]. Molecular mechanisms governing autophagy process, which can be divided into initiation, nucleation and elongation of autophagosome, fusion of autophagosome with the lysosome, and degradation of sequestered material, have been partially elucidated, and have also been widely exploited as novel biological targets in cancer therapies [101,102]. Autophagy is constitutively activated in cancer cells through the deregulation of PI3K/Akt/mTOR molecular axis and AMP-activated protein kinase (AMPK) signal transduction, which contributes to the metabolic reprogramming of cancer cells $[103,104]$.

Most evidence supports a context-dependent double-edged sword role of autophagy in cancer. Autophagy on one hand, due to its damage-mitigation effect, limits tumorigenesis, while actually promoting cancer cells fitness due to its pro-survival role in stress conditions, on the other [105]. These apparently contradictory phenomena have been detected in several types of cancer, including GC, in which autophagy-related proteins, such as Beclin 1 (BECN1), microtubule-associated protein 1 light chain 3 (MAP1-LC3), and p62/sequestosome 1 (SQSTM1) have an important prognostic value. Long-term Helicobacter pylori infection has been reported to promote gastric tumorigenesis by dramatically impairing autophagy that, in turn, is able to modulate pathological processes, such as GC metastasis, by affecting TME [106,107]. In consideration of its multifaceted roles in sustaining cell survival, it is not surprising that autophagy acts as a protective mechanism for tumor cells in chemotherapy, promoting drug resistance as well [108].

One of the most recent pieces of evidence regarding this is the significant association found between the autophagy-related gene-5 (ATG-5) over-expression and poor overall survival in GC patients, and its involvement in CDDP chemo-resistance in vitro [109]. Furthermore, autophagy has also been identified as one of the molecular mechanisms by which metadherin induces 5-FU resistance in the GC MKN45 cell line [110].

Moreover, An et al. demonstrated that an ATG12-dependent autophagy regulatory loop, inhibited by miR-23b-3p, has a major role in favoring GC cells drug resistance [111]. Moreover, GC cells CDDP resistance, associated with aquaporin 3 (AQP3) over-expression, is mediated by autophagy activation and reversed by the autophagy inhibitor chloroquine [112]. Autophagic flux may also be implicated in HER2-positive human GC NCI-N87 cells to trastuzumab [113].

\section{Multidrug Resistance (MDR) Mechanisms in GC}

Multidrug resistance (MDR) consists of different mechanisms that make cancer cells resistant to several structurally and mechanistically unrelated drugs at the same time. MDR occurs as a selection process of a cancer cell population during the administration of an anticancer agent. Widespread studies have been carried out to reveal the molecular mechanisms of drug resistance in cancer cells, which fall in two main categories: (a) drug-targeted mechanisms (changes in uptake, efflux, and metabolism of anticancer agents), and (b) drug cytotoxic effect compensation mechanisms (drug target mutation or expression modulation, cell cycle arrest, increased DNA repair, reduced apoptosis, etc.).

Regarding GC, several studies have investigated the mechanisms responsible for MDR and identified several genes in drug-resistant GC cell lines. Among these, many are different from those reported for hematopoietic or other solid tumors. For example, Zhao et al. reported a set of genes differentially expressed in two drug-resistant human gastric adenocarcinoma cell lines, SGC7901/VCR (resistant to vincristine) and SGC7901/ADR (resistant to adriamycin), as compared with their parental cell line SGC7901 [114]. Below, we reported the state of art in knowledge of MDR mechanisms in GC.

\subsection{Role of ATP-Binding Cassette (ABC) Transporters}

Increased drug efflux is a MDR mechanism that involves ATP-binding cassette (ABC) transporters that physiologically play a major role in the transport of nutrients and other molecules across the membrane. It has been demonstrated that $A B C$ transporters are often overexpressed in GC tumors and associated with chemo-resistance. P-glycoprotein (P-gp or MDR-1 or ABCB1) is one of the most investigated $A B C$ transporters, and was found to be overexpressed in GC and associated with a 
shorter survival in GC patients [115,116]. With respect to the correlation between P-gp and GC chemo-resistance, controversial results have been reported. These high expression levels were not, indeed, predictive of a poor prognosis in GC patients treated with 5-FU and DOX-based adjuvant chemotherapy [117]. P-gp was also determined to be dispensable for MDR occurrence in GC cell lines [118] and gastric tissue samples [119]. On the contrary, Chung et al. reported that P-gp expression rate increased from $27.8 \%$ to $37.5 \%$ pre to post administration of DOX, and correlated with a higher rate of systemic recurrence of GC [120]. Interestingly, targeting of Wnt/ $\beta$-catenin pathway, which directly controls P-gp expression, induced P-gp levels reduction and MDR reversion in GC cells [121]. Similar scenarios have been found in GC samples expressing the transcriptional factor NRF2, which induces P-gp expression. NRF2 expression was also found to strongly correlate with tumor size, histological grade, lymph node, and distant metastasis [122].

Other $\mathrm{ABC}$ transporters, such as $\mathrm{ABCC} 1$ and $\mathrm{ABCC} 2$, are associated with MDR in GC. Indeed, $\mathrm{Xu}$ et al. showed that $\mathrm{ABCC} 1$ and $\mathrm{P}$-gp positive expression rates were significantly higher in primary gastric cancer GC cells resistant to DOX, etoposide (VP-16), and hydroxycamptothecin (HCPT) [123]. However, it was found that both GC and the adjacent normal mucosa express high levels of $\mathrm{ABCCl}$ protein [124]. Furthermore, in advanced GC patients treated with 5-FU and DOX-based adjuvant chemotherapy, ABCC1 expression did not predict poor prognosis [117]. On the other hand, Li et al. reported that the $A B C C 2$ polymorphism rs717620 genotypes were associated with different response to neoadjuvant chemotherapy in a cohort of advanced GC patients treated with oxaliplatin and fluoropyrimidines [125]. Patients with CC genotype had poorer outcomes and responded 3.8 times less to chemotherapy than those with TT and TC genotypes.

Solute carriers (SLCs) are membrane transport proteins whose expression is known to be associated with sensitivity to chemotherapy as for SLC29A1 and SLC22A2, which play a critical role in the uptake of gemcitabine and 5-FU, respectively [126,127]. Shimakata el al. observed that Alfa-fetoprotein (AFP)-producing GC expresses both SLC29A1 and SLC22A2 at high levels, thus suggesting that patients with this aggressive subtype of GC could benefit from gemcitabine/5-FU combination therapy [128].

\subsection{Increased Drug Detoxification}

The Glutathione S-transferases (GSTs) is a family of enzymes that plays a pivotal role in cellular detoxification against a variety of xenobiotics and noxious compounds by catalyzing their conjugation with reduced glutathione (GSH) [129]. The expression levels of GST were significantly higher in GC compared to normal gastric mucosa [130]. In addition, GST overexpression has been suggested to be involved in CDDP resistance in MKN45 GC cell line [131]. Among patients treated with fluorinated pyrimidines and mitomycin C (MMC)-based chemotherapy, the GST-pi-negative group showed a higher rate of 5-years disease-free survival (DFS) than the GST-pi-positive group [132]. Indeed, primary single-cell suspensions resistant to 5-FU, CDDP and MMC, isolated from primary gastric cancers, express high levels of GST-pi [133]. In contrast, it was found that the GSH, GST activity and GST-pi levels before the start of therapy were not predictive of response. However, GSH and GST parameters were found increased in GC patients experiencing a response to chemotherapy as compared with progressive patients [134]. Similarly, slightly increased GST-pi expression was observed in gastric tumor samples compared with adjacent normal gastric mucosa and this GST-pi expression did not correlate with CDDP resistance [135]. The inconsistent results regarding the role of GST-pi in GC chemo-sensitivity imply that many additional factors are involved in MDR and the effective role of GST-pi in GC drug resistance needs to be clarified.

Synthesis of reduced GSH is also promoted by the interaction of CD44 splice variants (CD44v) with the $\mathrm{xCT}$ subunit of the cystine-glutamate exchange transporter (xc-) and is associated with resistance to oxidative stress $[136,137]$. This mechanism could explain the association between CD44v expression and high recurrence risk in GC patients $[138,139]$. Two clinical trials by Shitara et al. showed that the inhibition of xc- system by sulfasalazine (SSZ) reduces the levels of CD44v-positive cells and GSH in some GC patients, even in those refractory to CDDP $[140,141]$. 


\subsection{Counteracting Drug-Induced DNA Damage Response}

The main desirable effect of chemotherapeutic drugs is to induce massive cell death in tumor cells by apoptosis. A body of evidence indicates that chemo-resistance is possibly due to a defective apoptotic pathway. p53 is a tumor suppressor protein whose inactivation could be associated with resistance to chemotherapy in GC cells. Indeed, wild-type p53 expression in GC cell lines is significantly associated with response to CDDP and 5-FU as compared with mutant p53 expression [142]. Another study reported a significant up-regulation of p27 and a down-regulation of p53 and p21 in GC cell lines chronically exposed to CDDP. These results indicate a possible role for p27-dependent cell cycle arrest in CDDP-induced apoptosis escaping in GC cells [143]. Treatment with the recombinant adenoviral vector encoding the wild-type human tumor-suppressor protein p53 gene (rAd-p53) inhibited the growth of three GC cell lines and synergistically enhanced their sensitivity to oxaliplatin [144]. However, the response rate of patients with p53-negative locally advanced GC to epi-doxorubicin or 5-FU-based chemotherapy was found to be significantly higher when compared to patients with overexpression of p53 [145]. Despite these contrasting results, a recent meta-analysis demonstrated that p53 expression is positively linked to a better chemotherapy response in GC patients [146]. In a GC cell line, it was also demonstrated that the administration of parthenolide reverses drug-resistance to CDDP by inducing p53 expression [147]. Moreover, it was found that overexpression of homeobox A13 (HOXA13) gene makes GC cells more resistant to 5-FU by a p53-dependent pathway [148]. Similarly, overexpression of inhibition of apoptosis-stimulating protein of p53 (iASPP) was reported in GC patients, as well as in CDDP-resistant GC cell lines [149]. In response to DNA damage, p53 can bind epsin 3 (EPN3) promoter and induce its expression. EPN3 was found down-regulated in GC samples, and its knock-down resulted in resistance to DNA damage-induced apoptosis [150]. Notably, G2 and S-Phase Expressed 1 (GTSE1) gene, a p53 activity repressor, was found to be dose-dependently induced by CDDP treatment in GC cells and its knock-down enhanced p53-mediated apoptosis in response to CDDP [151]. NF- $\mathrm{KB}$ also plays a role in compensating p53 activity. Indeed, it was shown that 5-FU treatment determines the NF- $\mathrm{kB}$-dependent up-regulation of different p53 targets and that cell lines bearing Pro/Pro homozygosity at codon 72 of p53 exon 4 are more prone to 5-FU resistance [152]. Another strategy of GC cells for avoiding apoptosis pathway is that of regulating intracellular $\mathrm{Ca}^{2+}$ levels by the modulation of the expression and/or the activity of a multitude of $\mathrm{Ca}^{2+}$ channels and transporter proteins. We recently investigated this issue, and we found that the transient receptor potential cation channel subfamily V member 2 (TRPV2) is up-regulated in GC samples when compared with normal ones. TRPV2 expression levels are associated with worse prognosis in both overall and adjuvant-treated patients [153].

The acquisition of MDR can derive from the induction of DNA repair machinery, as hypothesized for the suppression of bridging integrator 1 (BIN1) protein by c-Myc overexpression, which gains DNA repair activity and confers CDDP resistance to GC cells [154]. The chemo-resistance prediction capability of the up-regulation of two nucleotide excision repair (NER) machinery genes was documented in a phase II study. Chemo-resistance prediction accuracy was $77.5 \%$ for damage DNA binding protein complex subunit 2 (DDB2), 75.0\% for excision repair cross-complementing 1 (ERCC1), and $82.5 \%$ when combined in GC patients treated with docetaxel, CDDP, and S-1 combination chemotherapy [155]. Furthermore, Ning et al. found that DNA double-strand breaks, induced by anticancer drugs, increase telomeric repeat binding protein 2 (TRF2) expression before ATM- and p53-dependent DNA damage response activation [156]. Moreover, increased telomerase reverse transcriptase (hTERT) was found in GC samples when compared with their matched normal mucosa, and its upregulation was associated with resistance to 5-FU and DOX in GC cells [157].

\subsection{Compensation of Drug Activity by Modulation of Targets Expression}

An alternative mechanism by which GC cells can escape from drug-induced cell death is represented by the up- or down-regulation of drug targets. In this scenario, the alteration in methylation pattern is relevant for response to treatment and patient survival. DNA methyltransferases 
(DNMTs) modulate the expression of genes involved in cell cycle regulation, genomic instability, EMT, apoptosis and tumor suppression [158]. Moreover, Topoisomerase II (Topo II), a nuclear enzyme involved in DNA replication, is an example of a drug target whose expression is often found down-regulated in GC. Indeed, it was demonstrated that in GC cells resistant to HCPT, DOX and MMC, Topo II down-regulation impaired cross-linked DNA formation [133]. The opposite mechanism involves the overexpression of thymidylate synthase (TS) enzyme, on which 5-FU acts, avoiding its binding to the natural substrate. Indeed, higher TS expression may predict drug resistance to 5-FU treated GC patients [159].

\section{Conclusions}

As for other types of cancer, drug resistance in GC is a major challenge into the clinical approach to patients. As summarized in Figure 1, several mechanisms have been implicated in the cellular and molecular modifications that make GC cells resistant to current chemotherapeutics strategies. In addition, GC cells are also able to, directly or indirectly, induce a deep and fine TME reorganization to their advantage. Deciphering and targeting these multifaceted GC cells' remodeling processes could be useful for adapting the current chemotherapeutic drugs to the GC cells' responsiveness, as well as in the setting up of novel tailored anticancer agents.

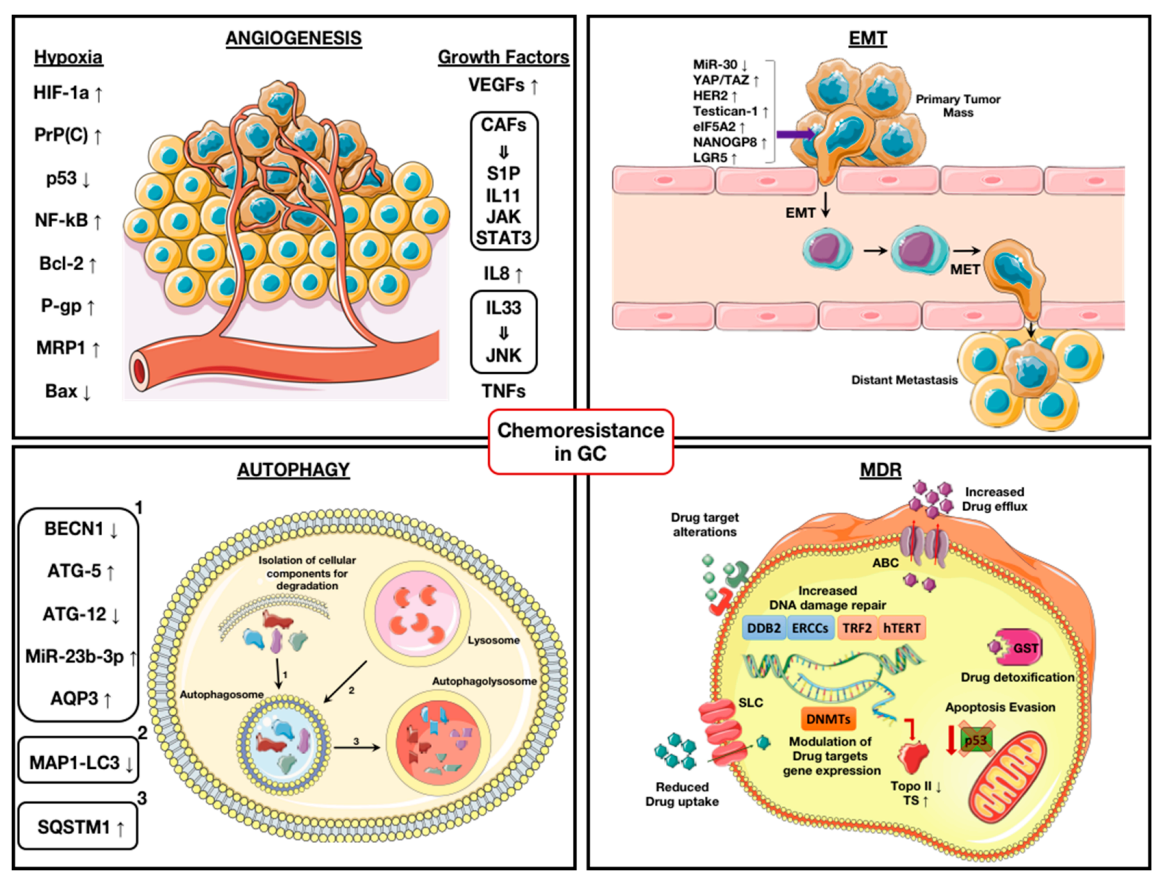

Figure 1. Schematic representation of the most common mechanisms involved in chemo-resistance of gastric cancer (GC) cells. Angiogenesis: hypoxia regulated genes and growth factors released by GC and cancer-associated fibroblasts (CAFs) implicated in chemo-resistance. Epithelial-Mesenchymal Transition (EMT): factors involved in epithelial-mesenchymal switch that makes cancer cells drug-resistant and able to metastasize. Autophagy: proteins involved in (1) isolation of cellular components for degradation in autophagosome, (2) fusion between autophagosome and lysosome, and (3) catabolic processes in autophagolysosome and found associated with chemo-resistance. Multidrug Resistance (MDR): proteins involved in reduced drug uptake or increased drug efflux; increased drug detoxification; mutation or down-regulation of drug targets; up-regulation of drug targets; increased drug-induced DNA damage repair or telomere maintenance pathways; epigenetic regulation of gene expression. Abbreviations: solute carrier (SLC) and ATP-binding cassette (ABC) transporters; glutathione S-transferase (GST); Topo II (Topoisomerase II); thymidylate synthase (TS); DNA methyltransferases (DNMTs). (Images built with illustrations from https://smart.servier.com under CC 3.0 license). 
Author Contributions: Conceptualization, S.R., H.K.V. and P.M.; resources, S.L., P.Z., G.C., F.L.R. and V.L.; writing-original draft preparation, S.R., H.K.V., S.L. and V.R.; writing-review and editing, G.S., A.N., A.S., G.F. and V.R.; supervision, G.F. and V.R.

Funding: This work was supported by current research funds, Italian Ministry of Health, to IRCCS-CROB, Rionero in Vulture, Potenza, Italy.

Conflicts of Interest: The authors declare no conflict of interest.

\section{Abbreviations}

$\begin{array}{ll}\text { GC } & \text { Gastric cancer } \\ \text { EMT } & \text { Epithelial-mesenchymal transition } \\ \text { TME } & \text { Tumor microenvironment } \\ \text { ECM } & \text { Extracellular matrix } \\ \text { CDDP } & \text { Cisplatin } \\ \text { 5-FU } & \text { F-fluorouracil } \\ \text { P-gp } & \text { P-glycoprotein } \\ \text { VEGF } & \text { Vascular endothelial growth factor } \\ \text { CAFs } & \text { Cancer-associated fibroblasts } \\ \text { ILs } & \text { Interleukins } \\ \text { CSCs } & \text { Cancer stem cells } \\ \text { MET } & \text { Mesenchymal-epithelial transition } \\ \text { DOX } & \text { Doxorubicin } \\ \text { MDR } & \text { Multidrug resistance } \\ \text { ABC } & \text { ATP-binding cassette transporters } \\ \text { HCPT } & \text { Hydroxycamptothecin } \\ \text { SLCs } & \text { Solute carrier transporters } \\ \text { GSH } & \text { Glutathione } \\ \text { Topo II } & \text { Topoisomerase II }\end{array}$

\section{References}

1. Sitarz, R.; Skierucha, M.; Mielko, J.; Offerhaus, G.J.A.; Maciejewski, R.; Polkowski, W.P. Gastric cancer: Epidemiology, prevention, classification, and treatment. Cancer Manag. Res. 2018, 10, 239-248. [CrossRef] [PubMed]

2. Marqués-Lespier, J.M.; González-Pons, M.; Cruz-Correa, M. Current perspectives on gastric cancer. Gastroenterol. Clin. N. Am. 2016, 45, 413-428. [CrossRef]

3. Torre, L.A.; Siegel, R.L.; Ward, E.M.; Jemal, A. Global Cancer Incidence and Mortality Rates and Trends-An Update. Cancer Epidemiol. Biomarkers Prev. 2016, 25, 16-27. [CrossRef] [PubMed]

4. Orditura, M.; Galizia, G.; Sforza, V.; Gambardella, V.; Fabozzi, A.; Laterza, M.M.; Andreozzi, F.; Ventriglia, J.; Savastano, B.; Mabilia, A.; et al. Treatment of gastric cancer. World J. Gastroenterol. 2014, 20, 1635-1649. [CrossRef] [PubMed]

5. Dicken, B.J.; Bigam, D.L.; Cass, C.; Mackey, J.R.; Joy, A.A.; Hamilton, S.M. Gastric adenocarcinoma: Review and considerations for future directions. Ann. Surg. 2005, 241, 27-39. [CrossRef] [PubMed]

6. Quadri, H.S.; Hong, Y.K.; Al-Refaie, W.B. Approach to the surgical management of resectable gastric cancer. Clin. Adv. Hematol. Oncol. 2016, 14, 249-257.

7. Hamamoto, Y. Complications in advanced or recurrent gastric cancer patients with peritoneal metastasis during and after palliative systemic chemotherapy. Mol. Clin. Oncol. 2015, 3, 539-542. [CrossRef]

8. Liu, D.; Lu, M.; Li, J.; Yang, Z.; Feng, Q.; Zhou, M.; Zhang, Z.; Shen, L. The patterns and timing of recurrence after curative resection for gastric cancer in China. World J. Surg. Oncol. 2016, 14, 305. [CrossRef]

9. Shin, C.H.; Lee, W.Y.; Hong, S.W.; Chang, Y.G. Characteristics of gastric cancer recurrence five or more years after curative gastrectomy. Chin. J. Cancer Res. 2016, 28, 503-510. [CrossRef]

10. Chon, S.H.; Berlth, F.; Plum, P.S.; Herbold, T.; Alakus, H.; Kleinert, R.; Moenig, S.P.; Bruns, C.J.; Hoelscher, A.H.; Meyer, H.J. Gastric cancer treatment in the world: Germany. Transl. Gastroenterol. Hepatol. 2017, 2, 53. [CrossRef] 
11. Kuo, C.Y.; Chao, Y.; Li, C.P. Update on treatment of gastric cancer. J. Chin. Med. Assoc. 2014, 77, $345-353$. [CrossRef] [PubMed]

12. Yang, Y.; Yin, X.; Sheng, L.; Xu, S.; Dong, L.; Liu, L. Perioperative chemotherapy more of a benefit for overall survival than adjuvant chemotherapy for operable gastric cancer: An updated Meta-analysis. Sci. Rep. 2015, 5, 12850. [CrossRef] [PubMed]

13. Jain, V.K.; Cunningham, D.; Rao, S. Chemotherapy for operable gastric cancer: Current perspectives. Indian J. Surg. Oncol. 2011, 2, 334-342. [CrossRef] [PubMed]

14. Jiang, W.G.; Sanders, A.J.; Katoh, M.; Ungefroren, H.; Gieseler, F.; Prince, M.; Thompson, S.K.; Zollo, M.; Spano, D.; Dhawan, P.; et al. Tissue invasion and metastasis: Molecular, biological and clinical perspectives. Semin. Cancer Biol. 2015, 35 Suppl, S244-S275. [CrossRef]

15. Gao, J.P.; Xu, W.; Liu, W.T.; Yan, M.; Zhu, Z.G. Tumor heterogeneity of gastric cancer: From the perspective of tumor-initiating cell. World J. Gastroenterol. 2018, 24, 2567-2581. [CrossRef]

16. Martin, T.A.; Ye, L.; Sanders, A.J.; Lane, J.; Jiang, W.G. Cancer Invasion and Metastasis: Molecular and Cellular Perspective, Madame Curie Bioscience Database-NCBI Bookshelf. 2013. Available online: https://www.ncbi.nlm.nih.gov/books/NBK164700/ (accessed on 20 June 2019).

17. Mansoori, B.; Mohammadi, A.; Davudian, S.; Shirjang, S.; Baradaran, B. The different mechanisms of cancer drug resistance: A brief review. Adv. Pharm. Bull. 2017, 7, 339-348. [CrossRef]

18. Lordick, F.; Allum, W.; Carneiro, F.; Mitry, E.; Tabernero, J.; Tan, P.; Van Cutsem, E.; van de Velde, C.; Cervantes, A. Unmet needs and challenges in gastric cancer: The way forward. Cancer Treat. Rev. 2014, 40, 692-700. [CrossRef]

19. Gottesman, M.M. Mechanisms of cancer drug resistance. Annu. Rev. Med. 2002, 53, 615-627. [CrossRef]

20. Lazăr, D.C.; Tăban, S.; Cornianu, M.; Faur, A.; Goldiş, A. New advances in targeted gastric cancer treatment. World J. Gastroenterol. 2016, 22, 6776-6799. [CrossRef]

21. Cao, W.; Wei, W.; Zhan, Z.; Xie, D.; Xie, Y.; Xiao, Q. Regulation of drug resistance and metastasis of gastric cancer cells via the microRNA647-ANK2 axis. Int. J. Mol. Med. 2018, 41, 1958-1966. [CrossRef]

22. Shi, W.J.; Gao, J.B. Molecular mechanisms of chemoresistance in gastric cancer. World J. Gastrointest. Oncol. 2016, 8, 673-681. [CrossRef] [PubMed]

23. Kim, H.K.; Choi, I.J.; Kim, C.G.; Kim, H.S.; Oshima, A.; Michalowski, A.; Green, J.E. A gene expression signature of acquired chemoresistance to cisplatin and fluorouracil combination chemotherapy in gastric cancer patients. PLoS ONE 2011, 6, e16694. [CrossRef] [PubMed]

24. Chung, H.W.; Lim, J.B. Role of the tumor microenvironment in the pathogenesis of gastric carcinoma. World J. Gastroenterol. 2014, 20, 1667-1680. [CrossRef] [PubMed]

25. Cho, J.; Chang, Y.H.; Heo, Y.J.; Kim, S.; Kim, N.K.; Park, J.O.; Kang, W.K.; Lee, J.; Kim, K.M. Four distinct immune microenvironment subtypes in gastric adenocarcinoma with special reference to microsatellite instability. ESMO Open 2018, 3, e000326. [CrossRef] [PubMed]

26. Testerman, T.L.; Morris, J. Beyond the stomach: An updated view of Helicobacter pylori pathogenesis, diagnosis, and treatment. World J. Gastroenterol. 2014, 20, 12781-12808. [CrossRef]

27. Qu, Y.; Dang, S.; Hou, P. Gene methylation in gastric cancer. Clin. Chim. Acta 2013, 424, 53-65. [CrossRef] [PubMed]

28. Selaru, F.M.; David, S.; Meltzer, S.J.; Hamilton, J.P. Epigenetic events in gastrointestinal cancer. Am. J. Gastroenterol. 2009, 104, 1910-1912. [CrossRef]

29. Yang, Q.; Zhu, C.; Zhang, Y.; Wang, Y.; Wang, Y.; Zhu, L.; Yang, X.; Li, J.; Nie, H.; Jiang, S.; et al. Molecular analysis of gastric cancer identifies genomic markers of drug sensitivity in Asian gastric cancer. J. Cancer 2018, 9, 2973-2980. [CrossRef]

30. Roma-Rodrigues, C.; Mendes, R.; Baptista, P.V.; Fernandes, A.R. Targeting tumor microenvironment for cancer therapy. Int. J. Mol. Sci. 2019, 20, 840. [CrossRef]

31. Senthebane, D.A.; Rowe, A.; Thomford, N.E.; Shipanga, H.; Munro, D.; Mazeedi, M.A.M.A.; Almazyadi, H.A.M.; Kallmeyer, K.; Dandara, C.; Pepper, M.S.; et al. The role of tumor microenvironment in chemoresistance: To survive, keep your enemies closer. Int. J. Mol. Sci. 2017, 18, 1568. [CrossRef]

32. Chen, D.; Zhang, X. Tipping Tumor Microenvironment against Drug Resistance. J. Oncol. Transl. Res. 2017, 1, 106. [CrossRef] 
33. Jo, Y.; Choi, N.; Kim, K.; Koo, H.J.; Choi, J.; Kim, H.N. Chemoresistance of Cancer Cells: Requirements of Tumor Microenvironment-mimicking In Vitro Models in Anti-cancer Drug Development. Theranostics 2018, 8, 5259-5275. [CrossRef] [PubMed]

34. Mumenthaler, S.M.; Foo, J.; Choi, N.C.; Heise, N.; Leder, K.; Agus, D.B.; Pao, W.; Michor, F.; Mallick, P. The impact of microenvironmental heterogeneity on the evolution of drug resistance in cancer cells. Cancer Inform. 2015, 14, 19-31. [CrossRef] [PubMed]

35. Affo, S.; Yu, L.X.; Schwabe, R.F. The Role of Cancer-Associated Fibroblasts and Fibrosis in Liver Cancer. Annu. Rev. Pathol. 2017, 12, 153-186. [CrossRef] [PubMed]

36. Shin, J.W.; Mooney, D.J. Extracellular matrix stiffness causes systematic variations in proliferation and chemosensitivity in myeloid leukemias. Proc. Natl. Acad. Sci. USA 2016, 113, 12126-12131. [CrossRef]

37. Jang, M.; Koh, I.; Lee, J.E.; Lim, J.Y.; Cheong, J.H.; Kim, P. Increased extracellular matrix density disrupts E-cadherin/ $\beta$-catenin complex in gastric cancer cells. Biomater. Sci. 2018, 6, 2704-2713. [CrossRef]

38. Ji, R.; Zhang, B.; Zhang, X.; Xue, J.; Yuan, X.; Yan, Y.; Wang, M.; Zhu, W.; Qian, H.; Xu, W. Exosomes derived from human mesenchymal stem cells confer drug resistance in gastric cancer. Cell Cycle 2015, 14, 2473-2483. [CrossRef]

39. Jang, M.; Koh, I.; Lee, S.J.; Cheong, J.H.; Kim, P. Droplet-based microtumor model to assess cell-ECM interactions and drug resistance of gastric cancer cells. Sci. Rep. 2017, 7, 41541. [CrossRef]

40. Nienhüser, H.; Schmidt, T. Angiogenesis and Anti-angiogenic Therapy in Gastric Cancer. Int. J. Mol. Sci. 2017, 19, 43. [CrossRef]

41. Hanahan, D.; Weinberg, R.A. The hallmarks of cancer. Cell 2000, 100, 57-70. [CrossRef]

42. Michiels, C.; Tellier, C.; Feron, O. Cycling hypoxia: A key feature of the tumor microenvironment. Biochim. Biophys. Acta 2016, 1866, 76-86. [CrossRef] [PubMed]

43. Vaupel, P.; Mayer, A. Hypoxia in tumors: Pathogenesis-related classification, characterization of hypoxia subtypes, and associated biological and clinical implications. Adv. Exp. Med. Biol. 2014, 812, $19-24$. [CrossRef] [PubMed]

44. Muz, B.; de la Puente, P.; Azab, F.; Azab, A.K. The role of hypoxia in cancer progression, angiogenesis, metastasis, and resistance to therapy. Hypoxia (Auckl) 2015, 3, 83-92. [CrossRef] [PubMed]

45. Griffiths, E.A.; Pritchard, S.A.; Welch, I.M.; Price, P.M.; West, C.M. Is the hypoxia-inducible factor pathway important in gastric cancer? Eur. J. Cancer 2005, 41, 2792-2805. [CrossRef] [PubMed]

46. Kitajima, Y.; Miyazaki, K. The Critical Impact of HIF-1a on Gastric Cancer Biology. Cancers (Basel) 2013, 5, 15-26. [CrossRef] [PubMed]

47. Skvortsova, I.; Skvortsov, S.; Haidenberger, A.; Devries, A.; Nevinny-Stickel, M.; Saurer, M.; Lukas, P.; Seppi, T. Effects of paclitaxel and docetaxel on EGFR-expressing human carcinoma cells under normoxic versus hypoxic conditions in vitro. J. Chemother. 2004, 16, 372-380. [CrossRef]

48. Liang, J.; Bai, F.; Luo, G.; Wang, J.; Liu, J.; Ge, F.; Pan, Y.; Yao, L.; Du, R.; Li, X.; et al. Hypoxia induced overexpression of $\operatorname{PrP}(\mathrm{C})$ in gastric cancer cell lines. Cancer Biol. Ther. 2007, 6, 769-774. [CrossRef]

49. Rohwer, N.; Dame, C.; Haugstetter, A.; Wiedenmann, B.; Detjen, K.; Schmitt, C.A.; Cramer, T. Hypoxia-inducible factor 1alpha determines gastric cancer chemosensitivity via modulation of p53 and NF-kappaB. PLoS ONE 2010, 5, e12038. [CrossRef]

50. Nakamura, J.; Kitajima, Y.; Kai, K.; Mitsuno, M.; Ide, T.; Hashiguchi, K.; Hiraki, M.; Miyazaki, K. Hypoxia-inducible factor-1alpha expression predicts the response to 5-fluorouracil-based adjuvant chemotherapy in advanced gastric cancer. Oncol. Rep. 2009, 22, 693-699. [CrossRef]

51. Liu, L.; Ning, X.; Sun, L.; Zhang, H.; Shi, Y.; Guo, C.; Han, S.; Liu, J.; Sun, S.; Han, Z.; et al. Hypoxia-inducible factor-1 alpha contributes to hypoxia-induced chemoresistance in gastric cancer. Cancer Sci. 2008, 99, 121-128. [CrossRef]

52. Yashiro, M. Gastric cancer stem cells and resistance to cancer therapy. Chemotherapy (Los Angel) $2014,3$. [CrossRef]

53. Abdel-Rahman, O. Targeting vascular endothelial growth factor (VEGF) pathway in gastric cancer: Preclinical and clinical aspects. Crit. Rev. Oncol. Hematol. 2015, 93, 18-27. [CrossRef] [PubMed]

54. Partyka, R.; Gonciarz, M.; Jałowiecki, P.; Kokocińska, D.; Byrczek, T. VEGF and metalloproteinase 2 (MMP 2) expression in gastric cancer tissue. Med. Sci. Monit. 2012, 18, BR130-BR134. [CrossRef]

55. Ozdemir, F.; Akdogan, R.; Aydin, F.; Reis, A.; Kavgaci, H.; Gul, S.; Akdogan, E. The effects of VEGF and VEGFR-2 on survival in patients with gastric cancer. J. Exp. Clin. Cancer Res. 2006, 25, 83-88. [PubMed] 
56. Schimanski, C.C.; Schlaegel, F.; Jordan, M.; Moehler, M.; Sgourakis, G.; Drescher, D.G.; Galle, P.R.; Lang, H.; Gockel, I. VEGF-D correlates with metastatic disease in gastric cancer patients undergoing surgery. World J. Surg. 2011, 35, 1010-1016. [CrossRef] [PubMed]

57. Cho, H.J.; Kim, I.K.; Park, S.M.; Baek, K.E.; Nam, I.K.; Park, S.H.; Ryu, K.J.; Choi, J.; Ryu, J.; Hong, S.C.; et al. VEGF-C mediates RhoGDI2-induced gastric cancer cell metastasis and cisplatin resistance. Int. J. Cancer 2014, 135, 1553-1563. [CrossRef] [PubMed]

58. Yoshida, G.J.; Azuma, A.; Miura, Y.; Orimo, A. Activated fibroblast program orchestrates tumor initiation and progression; molecular mechanisms and the associated therapeutic strategies. Int. J. Mol. Sci. 2019, 20, 2256. [CrossRef] [PubMed]

59. Erdogan, B.; Webb, D.J. Cancer-associated fibroblasts modulate growth factor signaling and extracellular matrix remodeling to regulate tumor metastasis. Biochem. Soc. Trans. 2017, 45, 229-236. [CrossRef]

60. Bu, L.; Baba, H.; Yoshida, N.; Miyake, K.; Yasuda, T.; Uchihara, T.; Tan, P.; Ishimoto, T. Biological heterogeneity and versatility of cancer-associated fibroblasts in the tumor microenvironment. Oncogene 2019, 38, 4887-4901. [CrossRef]

61. Guo, X.; Oshima, H.; Kitmura, T.; Taketo, M.M.; Oshima, M. Stromal fibroblasts activated by tumor cells promote angiogenesis in mouse gastric cancer. J. Biol. Chem. 2008, 283, 19864-19871. [CrossRef]

62. Ma, J.; Song, X.; Xu, X.; Mou, Y. Cancer-Associated Fibroblasts Promote the Chemo-resistance in Gastric Cancer through Secreting IL-11 Targeting JAK/STAT3/Bcl2 Pathway. Cancer Res. Treat. 2019, 51, 194-210. [CrossRef]

63. Ma, Y.; Zhu, J.; Chen, S.; Li, T.; Ma, J.; Guo, S.; Hu, J.; Yue, T.; Zhang, J.; Wang, P.; et al. Activated gastric cancer-associated fibroblasts contribute to the malignant phenotype and 5-FU resistance via paracrine action in gastric cancer. Cancer Cell Int. 2018, 18, 104. [CrossRef]

64. Kuai, W.X.; Wang, Q.; Yang, X.Z.; Zhao, Y.; Yu, R.; Tang, X.J. Interleukin-8 associates with adhesion, migration, invasion and chemosensitivity of human gastric cancer cells. World J. Gastroenterol. 2012, 18, 979-985. [CrossRef]

65. Ye, X.L.; Zhao, Y.R.; Weng, G.B.; Chen, Y.C.; Wei, X.N.; Shao, J.P.; Ji, H. IL-33-induced JNK pathway activation confers gastric cancer chemotherapy resistance. Oncol. Rep. 2015, 33, 2746-2752. [CrossRef]

66. Huang, S.; Chen, M.; Shen, Y.; Shen, W.; Guo, H.; Gao, Q.; Zou, X. Inhibition of activated Stat3 reverses drug resistance to chemotherapeutic agents in gastric cancer cells. Cancer Lett. 2012, 315, 198-205. [CrossRef]

67. Yang, Z.; Guo, L.; Liu, D.; Sun, L.; Chen, H.; Deng, Q.; Liu, Y.; Yu, M.; Ma, Y.; Guo, N.; et al. Acquisition of resistance to trastuzumab in gastric cancer cells is associated with activation of IL-6/STAT3/Jagged-1/Notch positive feedback loop. Oncotarget 2015, 6, 5072-5087. [CrossRef]

68. Kang, Y.; Hu, W.; Bai, E.; Zheng, H.; Liu, Z.; Wu, J.; Jin, R.; Zhao, C.; Liang, G. Curcumin sensitizes human gastric cancer cells to 5 -fluorouracil through inhibition of the NF- $\mathrm{B}$ survival-signaling pathway. Onco Targets Ther. 2016, 9, 7373-7384. [CrossRef]

69. Kwon, O.H.; Kim, J.H.; Kim, S.Y.; Kim, Y.S. TWEAK/Fn14 signaling mediates gastric cancer cell resistance to 5-fluorouracil via NF-kB activation. Int. J. Oncol. 2014, 44, 583-590. [CrossRef]

70. Zhi, X.; Tao, J.; Xiang, G.; Cao, H.; Liu, Z.; Yang, K.; Lv, C.; Ni, S. APRIL induces cisplatin resistance in gastric cancer cells via activation of the NF-кB pathway. Cell Physiol. Biochem. 2015, 35, 571-585. [CrossRef]

71. Fuchs, C.S.; Tomasek, J.; Yong, C.J.; Dumitru, F.; Passalacqua, R.; Goswami, C.; Safran, H.; Dos Santos, L.V.; Aprile, G.; Ferry, D.R.; et al. Ramucirumab monotherapy for previously treated advanced gastric or gastro-oesophageal junction adenocarcinoma (REGARD): An international, randomised, multicentre, placebo-controlled, phase 3 trial. Lancet 2014, 383, 31-39. [CrossRef]

72. Wang, Z.; Dabrosin, C.; Yin, X.; Fuster, M.M.; Arreola, A.; Rathmell, W.K.; Generali, D.; Nagaraju, G.P.; El-Rayes, B.; Ribatti, D.; et al. Broad targeting of angiogenesis for cancer prevention and therapy. Semin. Cancer Biol. 2015, 35 Suppl, S224-S243. [CrossRef]

73. Thiery, J.P. Epithelial-mesenchymal transitions in tumour progression. Nat. Rev. Cancer 2002, 2, $442-454$. [CrossRef]

74. Caiazza, C.; Mallardo, M. The Roles of miR-25 and its Targeted Genes in Development of Human Cancer. Microrna 2016, 5, 113-119. [CrossRef]

75. Ruggieri, V.; Russi, S.; Zoppoli, P.; La Rocca, F.; Angrisano, T.; Falco, G.; Calice, G.; Laurino, S. The Role of MicroRNAs in the Regulation of Gastric Cancer Stem Cells: A Meta-Analysis of the Current Status. J. Clin. Med. 2019, 8, 639. [CrossRef] 
76. Peng, Z.; Wang, C.X.; Fang, E.H.; Wang, G.B.; Tong, Q. Role of epithelial-mesenchymal transition in gastric cancer initiation and progression. World J. Gastroenterol. 2014, 20, 5403-5410. [CrossRef]

77. Pastushenko, I.; Brisebarre, A.; Sifrim, A.; Fioramonti, M.; Revenco, T.; Boumahdi, S.; Van Keymeulen, A.; Brown, D.; Moers, V.; Lemaire, S.; et al. Identification of the tumour transition states occurring during EMT. Nature 2018, 556, 463-468. [CrossRef]

78. Wik, E.; Ræder, M.B.; Krakstad, C.; Trovik, J.; Birkeland, E.; Hoivik, E.A.; Mjos, S.; Werner, H.M.J.; Mannelqvist, M.; Stefansson, I.M.; et al. Lack of estrogen receptor- $\alpha$ is associated with epithelial-mesenchymal transition and PI3K alterations in endometrial carcinoma. Clin. Cancer Res. 2013, 19, 1094-1105. [CrossRef]

79. Oishi, N.; Kumar, M.R.; Roessler, S.; Ji, J.; Forgues, M.; Budhu, A.; Zhao, X.; Andersen, J.B.; Ye, Q.H.; Jia, H.L.; et al. Transcriptomic profiling reveals hepatic stem-like gene signatures and interplay of miR-200c and epithelial-mesenchymal transition in intrahepatic cholangiocarcinoma. Hepatology 2012, 56, 1792-1803. [CrossRef]

80. Taube, J.H.; Herschkowitz, J.I.; Komurov, K.; Zhou, A.Y.; Gupta, S.; Yang, J.; Hartwell, K.; Onder, T.T.; Gupta, P.B.; Evans, K.W.; et al. Core epithelial-to-mesenchymal transition interactome gene-expression signature is associated with claudin-low and metaplastic breast cancer subtypes. Proc. Natl. Acad. Sci. USA 2010, 107, 15449-15454. [CrossRef]

81. Fischer, K.R.; Durrans, A.; Lee, S.; Sheng, J.; Li, F.; Wong, S.T.C.; Choi, H.; El Rayes, T.; Ryu, S.; Troeger, J.; et al. Epithelial-to-mesenchymal transition is not required for lung metastasis but contributes to chemoresistance. Nature 2015, 527, 472-476. [CrossRef]

82. Zheng, X.; Carstens, J.L.; Kim, J.; Scheible, M.; Kaye, J.; Sugimoto, H.; Wu, C.C.; LeBleu, V.S.; Kalluri, R. Epithelial-to-mesenchymal transition is dispensable for metastasis but induces chemoresistance in pancreatic cancer. Nature 2015, 527, 525-530. [CrossRef]

83. Thiery, J.P.; Acloque, H.; Huang, R.Y.J.; Nieto, M.A. Epithelial-mesenchymal transitions in development and disease. Cell 2009, 139, 871-890. [CrossRef]

84. Mitra, A.; Mishra, L.; Li, S. EMT, CTCs and CSCs in tumor relapse and drug-resistance. Oncotarget 2015, 6, 10697-10711. [CrossRef]

85. Wang, L.L.; Zhang, X.H.; Zhang, X.; Chu, J.K. MiR-30a increases cisplatin sensitivity of gastric cancer cells through suppressing epithelial-to-mesenchymal transition (EMT). Eur. Rev. Med. Pharmacol. Sci. 2016, 20, 1733-1739.

86. Ge, L.; Li, D.-S.; Chen, F.; Feng, J.D.; Li, B.; Wang, T.J. TAZ overexpression is associated with epithelial-mesenchymal transition in cisplatin-resistant gastric cancer cells. Int. J. Oncol. 2017, 51, 307-315. [CrossRef]

87. Kim, H.P.; Han, S.W.; Song, S.H.; Jeong, E.G.; Lee, M.Y.; Hwang, D.; Im, S.A.; Bang, Y.J.; Kim, T.Y. Testican-1-mediated epithelial-mesenchymal transition signaling confers acquired resistance to lapatinib in HER2-positive gastric cancer. Oncogene 2014, 33, 3334-3341. [CrossRef]

88. Huang, D.; Duan, H.; Huang, H.; Tong, X.; Han, Y.; Ru, G.; Qu, L.; Shou, C.; Zhao, Z. Cisplatin resistance in gastric cancer cells is associated with HER2 upregulation-induced epithelial-mesenchymal transition. Sci. Rep. 2016, 6, 20502. [CrossRef]

89. Sun, J.; Xu, Z.; Lv, H.; Wang, Y.; Wang, L.; Ni, Y.; Wang, X.; Hu, C.; Chen, S.; Teng, F.; et al. eIF5A2 regulates the resistance of gastric cancer cells to cisplatin via induction of EMT. Am. J. Transl. Res. 2018, 10, 4269-4279.

90. Grygielewicz, P.; Dymek, B.; Bujak, A.; Gunerka, P.; Stanczak, A.; Lamparska-Przybysz, M.; Wieczorek, M.; Dzwonek, K.; Zdzalik, D. Epithelial-mesenchymal transition confers resistance to selective FGFR inhibitors in SNU-16 gastric cancer cells. Gastric Cancer 2016, 19, 53-62. [CrossRef]

91. Han, R.; Xiong, J.; Xiao, R.; Altaf, E.; Wang, J.; Liu, Y.; Xu, H.; Ding, Q.; Zhang, Q. Activation of $\beta$-catenin signaling is critical for doxorubicin-induced epithelial-mesenchymal transition in BGC-823 gastric cancer cell line. Tumour Biol. 2013, 34, 277-284. [CrossRef]

92. Mani, S.A.; Guo, W.; Liao, M.J.; Eaton, E.N.; Ayyanan, A.; Zhou, A.Y.; Brooks, M.; Reinhard, F.; Zhang, C.C.; Shipitsin, M.; et al. The epithelial-mesenchymal transition generates cells with properties of stem cells. Cell 2008, 133, 704-715. [CrossRef]

93. Ryu, H.S.; Park, D.J.; Kim, H.H.; Kim, W.H.; Lee, H.S. Combination of epithelial-mesenchymal transition and cancer stem cell-like phenotypes has independent prognostic value in gastric cancer. Hum. Pathol. 2012, 43, 520-528. [CrossRef] 
94. Ma, X.; Wang, B.; Wang, X.; Luo, Y.; Fan, W. NANOGP8 is the key regulator of stemness, EMT, Wnt pathway, chemoresistance, and other malignant phenotypes in gastric cancer cells. PLoS ONE 2018, 13, e0192436. [CrossRef]

95. Wang, B.; Chen, Q.; Cao, Y.; Ma, X.; Yin, C.; Jia, Y.; Zang, A.; Fan, W. LGR5 Is a Gastric Cancer Stem Cell Marker Associated with Stemness and the EMT Signature Genes NANOG, NANOGP8, PRRX1, TWIST1, and BMI1. PLoS ONE 2016, 11, e0168904. [CrossRef]

96. Feng, S.; Zheng, Z.; Feng, L.; Yang, L.; Chen, Z.; Lin, Y.; Gao, Y.; Chen, Y. Proton pump inhibitor pantoprazole inhibits the proliferation, self-renewal and chemoresistance of gastric cancer stem cells via the EMT/ $\beta$-catenin pathways. Oncol. Rep. 2016, 36, 3207-3214. [CrossRef]

97. Shipitsin, M.; Campbell, L.L.; Argani, P.; Weremowicz, S.; Bloushtain-Qimron, N.; Yao, J.; Nikolskaya, T.; Serebryiskaya, T.; Beroukhim, R.; Hu, M.; et al. Molecular definition of breast tumor heterogeneity. Cancer Cell 2007, 11, 259-273. [CrossRef]

98. Chen, H.T.; Liu, H.; Mao, M.J.; Tan, Y.; Mo, X.Q.; Meng, X.J.; Cao, M.T.; Zhong, C.Y.; Liu, Y.; Shan, H.; et al. Crosstalk between autophagy and epithelial-mesenchymal transition and its application in cancer therapy. Mol. Cancer 2019, 18, 101. [CrossRef]

99. Gugnoni, M.; Sancisi, V.; Manzotti, G.; Gandolfi, G.; Ciarrocchi, A. Autophagy and epithelial-mesenchymal transition: An intricate interplay in cancer. Cell Death Dis. 2016, 7, e2520. [CrossRef]

100. Mathew, R.; Karantza-Wadsworth, V.; White, E. Role of autophagy in cancer. Nat. Rev. Cancer 2007, 7, 961-967. [CrossRef]

101. Mizushima, N.; Yoshimori, T.; Ohsumi, Y. The role of Atg proteins in autophagosome formation. Annu. Rev. Cell Dev. Biol. 2011, 27, 107-132. [CrossRef]

102. Levy, J.M.M.; Towers, C.G.; Thorburn, A. Targeting autophagy in cancer. Nat. Rev. Cancer 2017, 17, 528-542. [CrossRef]

103. Yoshida, G.J. Therapeutic strategies of drug repositioning targeting autophagy to induce cancer cell death: From pathophysiology to treatment. J. Hematol. Oncol. 2017, 10, 67. [CrossRef]

104. Yoshida, G.J. Metabolic reprogramming: The emerging concept and associated therapeutic strategies. J. Exp. Clin. Cancer Res. 2015, 34, 111. [CrossRef]

105. White, E.; DiPaola, R.S. The double-edged sword of autophagy modulation in cancer. Clin. Cancer Res. 2009, 15, 5308-5316. [CrossRef]

106. Cao, Y.; Luo, Y.; Zou, J.; Ouyang, J.; Cai, Z.; Zeng, X.; Ling, H.; Zeng, T. Autophagy and its role in gastric cancer. Clin. Chim. Acta 2019, 489, 10-20. [CrossRef]

107. Qian, H.; Yang, Y. Functional role of autophagy in gastric cancer. Oncotarget 2016, 7, 17641-17651. [CrossRef]

108. Al-Akra, L.; Bae, D.H.; Leck, L.L.; Richardson, D.R.; Jansson, P.J. The biochemical and molecular mechanisms involved in the role of micro-tumor environment stress in development of drug resistance. Biochim. Biophys. Acta Gen. Subj. 2019. [CrossRef]

109. Ge, J.; Chen, Z.; Huang, J.; Chen, J.; Yuan, W.; Deng, Z.; Chen, Z. Upregulation of autophagy-related gene-5 (ATG-5) is associated with chemoresistance in human gastric cancer. PLoS ONE 2014, 9, e110293. [CrossRef]

110. Pei, G.; Luo, M.; Ni, X.; Wu, J.; Wang, S.; Ma, Y.; Yu, J. Autophagy Facilitates Metadherin-Induced Chemotherapy Resistance Through the AMPK/ATG5 Pathway in Gastric Cancer. Cell. Physiol. Biochem. 2018, 46, 847-859. [CrossRef]

111. An, Y.; Zhang, Z.; Shang, Y.; Jiang, X.; Dong, J.; Yu, P.; Nie, Y.; Zhao, Q. miR-23b-3p regulates the chemoresistance of gastric cancer cells by targeting ATG12 and HMGB2. Cell Death Dis. 2015, 6, e1766. [CrossRef]

112. Dong, X.; Wang, Y.; Zhou, Y.; Wen, J.; Wang, S.; Shen, L. Aquaporin 3 facilitates chemoresistance in gastric cancer cells to cisplatin via autophagy. Cell Death Discov. 2016, 2, 16087. [CrossRef]

113. Ye, H.; Chai, X.; Wang, X.; Zheng, Q.; Zheng, D.; Wu, F.; Zheng, C.; Chen, P. Autophagy flux inhibition augments gastric cancer resistance to the anti-human epidermal growth factor receptor 2 antibody trastuzumab. Oncol. Lett. 2018, 15, 4143-4150. [CrossRef]

114. Zhao, Y.; You, H.; Liu, F.; An, H.; Shi, Y.; Yu, Q.; Fan, D. Differentially expressed gene profiles between multidrug resistant gastric adenocarcinoma cells and their parental cells. Cancer Lett. 2002, 185, 211-218. [CrossRef] 
115. Gürel, S.; Yerci, O.; Filiz, G.; Dolar, E.; Yilmazlar, T.; Nak, S.G.; Gülten, M.; Zorluoğlu, A.; Memik, F. High expression of multidrug resistance-1 (MDR-1) and its relationship with multiple prognostic factors in gastric carcinomas in patients in Turkey. J. Int. Med. Res. 1999, 27, 79-84. [CrossRef]

116. de Oliveira, J.; Felipe, A.V.; Neto, R.A.; Oshima, C.T.; de Souza Silva, M.; Forones, N.M. Association between ABCB1 immunohistochemical expression and overall survival in gastric cancer patients. Asian Pac. J. Cancer Prev. 2014, 15, 6935-6938. [CrossRef]

117. Choi, J.H.; Lim, H.Y.; Joo, H.J.; Kim, H.S.; Yi, J.W.; Kim, H.C.; Cho, Y.K.; Kim, M.W.; Lee, K.B. Expression of multidrug resistance-associated protein1,P-glycoprotein, and thymidylate synthase in gastric cancer patients treated with 5-fluorouracil and doxorubicin-based adjuvant chemotherapy after curative resection. Br. J. Cancer 2002, 86, 1578-1585. [CrossRef]

118. Kellner, U.; Hutchinson, L.; Seidel, A.; Lage, H.; Danks, M.K.; Dietel, M.; Kaufmann, S.H. Decreased drug accumulation in a mitoxantrone-resistant gastric carcinoma cell line in the absence of P-glycoprotein. Int. J. Cancer 1997, 71, 817-824. [CrossRef]

119. Tomonaga, M.; Oka, M.; Narasaki, F.; Fukuda, M.; Nakano, R.; Takatani, H.; Ikeda, K.; Terashi, K.; Matsuo, I.; Soda, H.; et al. The multidrug resistance-associated protein gene confers drug resistance in human gastric and colon cancers. Jpn. J. Cancer Res. 1996, 87, 1263-1270. [CrossRef]

120. Chung, H.C.; Gong, S.J.; Yoo, N.C.; Noh, S.H.; Kim, J.H.; Roh, J.K.; Min, J.S.; Kim, B.S.; Lee, K.B. P-glycoprotein as an intermediate end point of drug resistance to neoadjuvant chemotherapy in locally advanced gastric cancer. Yonsei Med. J. 1996, 37, 397-404. [CrossRef]

121. Hou, G.; Yuan, X.; Li, Y.; Hou, G.; Liu, X. Cardamonin, a natural chalcone, reduces 5-fluorouracil resistance of gastric cancer cells through targeting Wnt/ $\beta$-catenin signal pathway. Invest. New Drugs 2019. [CrossRef]

122. Jeddi, F.; Soozangar, N.; Sadeghi, M.R.; Somi, M.H.; Shirmohamadi, M.; Eftekhar-Sadat, A.T.; Samadi, N. Nrf2 overexpression is associated with P-glycoprotein upregulation in gastric cancer. Biomed. Pharmacother. 2018, 97, 286-292. [CrossRef] [PubMed]

123. Xu, H.W.; Xu, L.; Hao, J.H.; Qin, C.Y.; Liu, H. Expression of P-glycoprotein and multidrug resistance-associated protein is associated with multidrug resistance in gastric cancer. J. Int. Med. Res. 2010, 38, 34-42. [CrossRef] [PubMed]

124. Lacueva, J.; Perez-Ramos, M.; Soto, J.L.; Oliver, I.; Andrada, E.; Medrano, J.; Perez-Vazquez, T.; Arroyo, A.; Carrato, A.; Ferragut, J.A.; et al. Multidrug resistance-associated protein (MRP1) gene is strongly expressed in gastric carcinomas. Analysis by immunohistochemistry and real-time quantitative RT-PCR. Histopathology 2005, 46, 389-395. [CrossRef] [PubMed]

125. Li, Z.; Xing, X.; Shan, F.; Li, S.; Li, Z.; Xiao, A.; Xing, Z.; Xue, K.; Li, Z.; Hu, Y.; et al. ABCC2-24C > T polymorphism is associated with the response to platinum/5-Fu-based neoadjuvant chemotherapy and better clinical outcomes in advanced gastric cancer patients. Oncotarget 2016, 7, 55449-55457. [CrossRef] [PubMed]

126. Mackey, J.R.; Mani, R.S.; Selner, M.; Mowles, D.; Young, J.D.; Belt, J.A.; Crawford, C.R.; Cass, C.E. Functional nucleoside transporters are required for gemcitabine influx and manifestation of toxicity in cancer cell lines. Cancer Res. 1998, 58, 4349-4357.

127. Kobayashi, Y.; Ohshiro, N.; Sakai, R.; Ohbayashi, M.; Kohyama, N.; Yamamoto, T. Transport mechanism and substrate specificity of human organic anion transporter 2 (hOat2 [SLC22A7]). J. Pharm. Pharmacol. 2005, 57, 573-578. [CrossRef] [PubMed]

128. Shimakata, T.; Kamoshida, S.; Kawamura, J.; Ogane, N.; Kameda, Y.; Yanagita, E.; Itoh, T.; Takeda, R.; Naka, A.; Sakamaki, K.; et al. Immunohistochemical expression profiles of solute carrier transporters in alpha-fetoprotein-producing gastric cancer. Histopathology 2016, 69, 812-821. [CrossRef]

129. McIlwain, C.C.; Townsend, D.M.; Tew, K.D. Glutathione S-transferase polymorphisms: Cancer incidence and therapy. Oncogene 2006, 25, 1639-1648. [CrossRef]

130. Peters, W.H.; Wormskamp, N.G.; Thies, E. Expression of glutathione S-transferases in normal gastric mucosa and in gastric tumors. Carcinogenesis 1990, 11, 1593-1596. [CrossRef]

131. Satta, T.; Isobe, K.; Yamauchi, M.; Nakashima, I.; Takagi, H. Expression of MDR1 and glutathione S transferase-pi genes and chemosensitivities in human gastrointestinal cancer. Cancer 1992, 69, 941-946. [CrossRef]

132. Monden, N.; Abe, S.; Sutoh, I.; Hishikawa, Y.; Kinugasa, S.; Nagasue, N. Prognostic significance of the expressions of metallothionein, glutathione-S-transferase-pi, and P-glycoprotein in curatively resected gastric cancer. Oncology 1997, 54, 391-399. [CrossRef] [PubMed] 
133. Geng, M.; Wang, L.; Chen, X.; Cao, R.; Li, P. The association between chemosensitivity and Pgp, GST- $\pi$ and Topo II expression in gastric cancer. Diagn. Pathol. 2013, 8, 198. [CrossRef] [PubMed]

134. Schipper, D.L.; Wagenmans, M.J.; Peters, W.H.; Wils, J.A.; Wagener, D.J. Glutathione S-transferases and iododeoxyuridine labelling index during chemotherapy of gastric cancer. Anticancer Res. 2000, 20, 1705-1710. [PubMed]

135. Kodera, Y.; Akiyama, S.; Isobe, K.; Kondo, K.; Ito, K.; Yamauchi, M.; Takagi, H. Expression of pi-glutathione S-transferase gene (GSTP1) in gastric cancer: Lack of correlation with resistance against cis-diamminedichloroplatinum (II). Eur. J. Cancer 1994, 30A, 2158-2162. [CrossRef]

136. Nagano, O.; Okazaki, S.; Saya, H. Redox regulation in stem-like cancer cells by CD44 variant isoforms. Oncogene 2013, 32, 5191-5198. [CrossRef] [PubMed]

137. Yoshida, G.J. The heterogeneity of cancer stem-like cells at the invasive front. Cancer Cell Int. 2017, 17, 23. [CrossRef]

138. Hirata, K.; Suzuki, H.; Imaeda, H.; Matsuzaki, J.; Tsugawa, H.; Nagano, O.; Asakura, K.; Saya, H.; Hibi, T. CD44 variant 9 expression in primary early gastric cancer as a predictive marker for recurrence. Br. J. Cancer 2013, 109, 379-386. [CrossRef]

139. Ishimoto, T.; Nagano, O.; Yae, T.; Tamada, M.; Motohara, T.; Oshima, H.; Oshima, M.; Ikeda, T.; Asaba, R.; Yagi, H.; et al. CD44 variant regulates redox status in cancer cells by stabilizing the xCT subunit of system xc(-) and thereby promotes tumor growth. Cancer Cell 2011, 19, 387-400. [CrossRef]

140. Shitara, K.; Doi, T.; Nagano, O.; Imamura, C.K.; Ozeki, T.; Ishii, Y.; Tsuchihashi, K.; Takahashi, S.; Nakajima, T.E.; Hironaka, S.; et al. Dose-escalation study for the targeting of CD44v+ cancer stem cells by sulfasalazine in patients with advanced gastric cancer (EPOC1205). Gastric Cancer 2017, 20, 341-349. [CrossRef]

141. Shitara, K.; Doi, T.; Nagano, O.; Fukutani, M.; Hasegawa, H.; Nomura, S.; Sato, A.; Kuwata, T.; Asai, K.; Einaga, Y.; et al. Phase 1 study of sulfasalazine and cisplatin for patients with CD44v-positive gastric cancer refractory to cisplatin (EPOC1407). Gastric Cancer 2017, 20, 1004-1009. [CrossRef]

142. Matsuhashi, N.; Saio, M.; Matsuo, A.; Sugiyama, Y.; Saji, S. Apoptosis induced by 5-fluorouracil, cisplatin and paclitaxel are associated with p53 gene status in gastric cancer cell lines. Int. J. Oncol. 2005, 26, 1563-1567. [CrossRef] [PubMed]

143. Le, T.V.T.; Seo, Y.; Ryu, C.J.; Lee, H.R.; Park, H.J. Increased expression of p27 is associated with the cisplatin resistance in gastric cancer cell line YCC-3. Arch. Pharm. Res. 2010, 33, 1127-1132. [CrossRef] [PubMed]

144. Chen, G.X.; Zheng, L.H.; Liu, S.Y.; He, X.H. rAd-p53 enhances the sensitivity of human gastric cancer cells to chemotherapy. World J. Gastroenterol. 2011, 17, 4289-4297. [CrossRef] [PubMed]

145. Cascinu, S.; Graziano, F.; Del Ferro, E.; Staccioli, M.P.; Ligi, M.; Carnevali, A.; Muretto, P.; Catalano, G. Expression of $\mathrm{p} 53$ protein and resistance to preoperative chemotherapy in locally advanced gastric carcinoma. Cancer 1998, 83, 1917-1922. [CrossRef]

146. Xu, H.Y.; Xu, W.L.; Wang, L.Q.; Chen, M.B.; Shen, H.L. Relationship between p53 status and response to chemotherapy in patients with gastric cancer: A meta-analysis. PLoS ONE 2014, 9, e95371. [CrossRef] [PubMed]

147. Li, H.; Lu, H.; Lv, M.; Wang, Q.; Sun, Y. Parthenolide facilitates apoptosis and reverses drug-resistance of human gastric carcinoma cells by inhibiting the STAT3 signaling pathway. Oncol. Lett. 2018, 15, 3572-3579. [CrossRef] [PubMed]

148. Han, Y.; Song, C.; Wang, J.; Tang, H.; Peng, Z.; Lu, S. HOXA13 contributes to gastric carcinogenesis through DHRS2 interacting with MDM2 and confers 5-FU resistance by a p53-dependent pathway. Mol. Carcinog. 2018, 57, 722-734. [CrossRef] [PubMed]

149. Yu, J.; Li, L.; Huang, C. Downregulation of Inhibition of Apoptosis-Stimulating Protein of p53 (iASPP) Suppresses Cisplatin-Resistant Gastric Carcinoma In Vitro. Med. Sci. Monit. 2017, 23, 5542-5549. [CrossRef]

150. Mori, J.; Tanikawa, C.; Ohnishi, N.; Funauchi, Y.; Toyoshima, O.; Ueda, K.; Matsuda, K. EPSIN 3, A novel p53 target, regulates the apoptotic pathway and gastric carcinogenesis. Neoplasia 2017, 19, 185-195. [CrossRef]

151. Subhash, V.V.; Tan, S.H.; Tan, W.L.; Yeo, M.S.; Xie, C.; Wong, F.Y.; Kiat, Z.Y.; Lim, R.; Yong, W.P. GTSE1 expression represses apoptotic signaling and confers cisplatin resistance in gastric cancer cells. BMC Cancer 2015, 15, 550. [CrossRef]

152. Endo, F.; Nishizuka, S.S.; Kume, K.; Ishida, K.; Katagiri, H.; Ishida, K.; Sato, K.; Iwaya, T.; Koeda, K.; Wakabayashi, G. A compensatory role of NF-kB to p53 in response to 5-FU-based chemotherapy for gastric cancer cell lines. PLoS ONE 2014, 9, e90155. [CrossRef] [PubMed] 
153. Zoppoli, P.; Calice, G.; Laurino, S.; Ruggieri, V.; La Rocca, F.; La Torre, G.; Ciuffi, M.; Amendola, E.; De Vita, F.; Petrillo, A.; et al. TRPV2 calcium channel gene expression and outcomes in gastric cancer patients: A clinically relevant association. J. Clin. Med. 2019, 8, 662. [CrossRef] [PubMed]

154. Tanida, S.; Mizoshita, T.; Ozeki, K.; Tsukamoto, H.; Kamiya, T.; Kataoka, H.; Sakamuro, D.; Joh, T. Mechanisms of Cisplatin-Induced Apoptosis and of Cisplatin Sensitivity: Potential of BIN1 to Act as a Potent Predictor of Cisplatin Sensitivity in Gastric Cancer Treatment. Int. J. Surg. Oncol. 2012, 2012, 862879. [CrossRef] [PubMed]

155. Hirakawa, M.; Sato, Y.; Ohnuma, H.; Takayama, T.; Sagawa, T.; Nobuoka, T.; Harada, K.; Miyamoto, H.; Sato, Y.; Takahashi, Y.; et al. A phase II study of neoadjuvant combination chemotherapy with docetaxel, cisplatin, and S-1 for locally advanced resectable gastric cancer: Nucleotide excision repair (NER) as potential chemoresistance marker. Cancer Chemother. Pharmacol. 2013, 71, 789-797. [CrossRef] [PubMed]

156. Ning, H.; Li, T.; Zhao, L.; Li, T.; Li, J.; Liu, J.; Liu, Z.; Fan, D. TRF2 promotes multidrug resistance in gastric cancer cells. Cancer Biol. Ther. 2006, 5, 950-956. [CrossRef] [PubMed]

157. Wang, L.; Li, P.F.; Geng, M.; Cao, Y.C.; Yin, Y.C. Correlation between chemosensitivity to anticancer drugs and telomerase reverse transcriptase mRNA expression in gastric cancer. Diagn. Pathol. 2013, 8, 33. [CrossRef]

158. Fattahi, S.; Golpour, M.; Amjadi-Moheb, F.; Sharifi-Pasandi, M.; Khodadadi, P.; Pilehchian-Langroudi, M.; Ashrafi, G.H.; Akhavan-Niaki, H. DNA methyltransferases and gastric cancer: Insight into targeted therapy. Epigenomics 2018, 10, 1477-1497. [CrossRef]

159. Gao, Y.; Cui, J.; Xi, H.; Cai, A.; Shen, W.; Li, J.; Zhang, K.; Wei, B.; Chen, L. Association of thymidylate synthase expression and clinical outcomes of gastric cancer patients treated with fluoropyrimidine-based chemotherapy: A meta-analysis. Onco Targets Ther. 2016, 9, 1339-1350. [CrossRef]

(C) 2019 by the authors. Licensee MDPI, Basel, Switzerland. This article is an open access article distributed under the terms and conditions of the Creative Commons Attribution (CC BY) license (http://creativecommons.org/licenses/by/4.0/). 